\title{
Combined Treatment with Intravitreal Bevacizumab and Intravitreal Triamcinolone in Retinal Vein Occlusion in Indian Eyes
}

\author{
Mansi Sharma ${ }^{1}$, Daraius Shroff ${ }^{2}$, Shishir Narain ${ }^{3}$, Cyrus M Shroff $^{4}$, Charu Gupta ${ }^{5}$
}

\begin{abstract}
Purpose: To study therapeutic efficacy of combination of intravitreal triamcinolone acetonide and intravitreal bevacizumab for treatment of macular edema associated with branch retinal vein occlusion (BRVO) and central retinal vein occlusion (CRVO).

Method: This prospective interventional study included 20 eyes of 20 patients with fresh retinal vein occlusion (RVO) of less than three months duration. Treatment involved intravitreal injection with $1.25 \mathrm{mg}$ bevacizumab and $1 \mathrm{mg}$ triamcinolone acetonide.

Result: The mean age of patients was 63.81 years. There were 10 patients each of BRVO and CRVO. Both groups showed significant improvement in mean baseline visual acuity, however BRVO patients fared better than CRVO patients at all visits. Mean baseline central macular thickness (CMT) in BRVO and CRVO patients was 381.70 microns, and 572.50 microns, respectively with mean reduction of 131.40 and 182.1 microns, respectively. This reduction was significant at all visits during the course of the follow-up.

Rise in intraocular pressure (IOP) $\geq 21 \mathrm{~mm} \mathrm{Hg}$ was found in 5 BRVO and 4 CRVO patients. Cataract development and progression was found 2 BRVO and 1 CRVO patient. There was no case of retinal detachment or endophthalmitis.

Conclusion: Combined treatment with intravitreal bevacizumab and intravitreal triamcinolone acetonide causes structural and functional improvement in form of reduction of macular edema and improvement in visual acuity in eyes with both BRVO and CRVO.

Keywords: Intravitreal bevacizumab, Intravitreal combined, Intravitreal triamcinolone, Retinal vein occlusion.

Journal of Postgraduate Medicine, Education and Research (2019): 10.5005/jp-journals-10028-1317
\end{abstract}

\section{INTRODUCTION}

$\mathrm{R}_{\mathrm{o}}^{\mathrm{e}}$ tinal vascular occlusion (RVO) is the second most common cause of the retinal vascular disease after diabetic retinopathy. ${ }^{1,2}$ There are mainly two types of retinal vein occlusions (RVO), central retinal vein occlusion (CRVO) and branch retinal vein occlusion (BRVO). This distinction is important as there are significant differences in the clinical features, and response to treatment, of each entity. ${ }^{3,4}$ The consequences of BRVO are similar to those seen in CRVO (hemorrhages, cotton wool patches, edema, capillary occlusion), but tend to be less severe because a portion of the retina has normal venous drainage.

The development of neovascularization in both CRVO and BRVO denoted advanced stage and is similarly treated with pan-retinal photocoagulation to the peripheral retina. The challenge lies in the management of macular edema, which is of recurrent nature in RVOs.The use of laser photocoagulation to treat diabetic macular edema prompted its use in branch vein occlusion. Studies proved grid laser to be of benefit in BRVO ${ }^{5}$ but not in cases of CRVO. ${ }^{6}$

Amongst the other various treatment options, intravitreal injections of depot steroids ${ }^{7-10}$ and anti-VEGF $F^{11-14}$ have become most popular. However, both the drugs are associated with transient benefits and recurrence of macular edema. Corticosteroids are used with the rationale that they reduce retinal capillary permeability, ${ }^{15}$ inhibit the expression of the VEGF gene and the metabolic pathway of VEGF. ${ }^{16}$ VEGF inhibitors are used as they are monoclonal antibodies that bind to isoforms of VEGF. ${ }^{17}$

Most studies with both the drugs have reported a recurrence of macular edema with the need for repeated injections. Recently combined pharmacological therapy (intravitreal anti-VEGF and corticosteroids) has been explored for management of macular edema. The rationale for the combined therapy ${ }^{18,19}$ is to treat
${ }^{1-5}$ Consultant Ophthalmologist

${ }^{1}$ Department of Ophthalmology, Grewal Eye Institute, Chandigarh, India

${ }^{2-5}$ Department of Ophthalmology, Shroff Eye Centre, New Delhi, India

Corresponding Author: Mansi Sharma, Consultant Ophthalmologist, Department of Ophthalmology, Grewal Eye Institute, Chandigarh, India, e-mail: dr.mansi.sharma@gmail.com

How to cite this article: Sharma M, Shroff D, Narain S, Shroff CM, Gupta C. Combined Treatment with Intravitreal Bevacizumab and Intravitreal Triamcinolone in Retinal Vein Occlusion in Indian Eyes. J Postgrad Med Edu Res 2019;53(2):75-78.

Source of support: Nil

Conflict of interest: None

both the antiangiogenic and anti-inflammatory components of the disease simultaneously and perhaps reduce the dosage and number of injections. We, thus conducted this study to explore the therapeutic efficacy of the combination of intravitreal triamcinolone acetonide and intravitreal bevacizumab for the treatment of macular edema associated with branch retinal vein occlusion and central retinal vein occlusion.

\section{Materials AND METHOdS}

A prospective interventional study was conducted at the retina clinic in Shroff Eye Centre between June 2010 and October 2012. We included all patients presenting with retinal vein occlusion (RVO) with symptoms of less than 3 months duration who has not received any intravitreal or subtenons steroids or anti-VEGF agents or any macular photocoagulation. Exclusion criteria included: IOP $>21 \mathrm{~mm} \mathrm{Hg}$ at presentation, history of intravitreal steroids,

(c) The Author(s). 2019 Open Access This article is distributed under the terms of the Creative Commons Attribution 4.0 International License (https://creativecommons. org/licenses/by-nc/4.0/), which permits unrestricted use, distribution, and non-commercial reproduction in any medium, provided you give appropriate credit to the original author(s) and the source, provide a link to the Creative Commons license, and indicate if changes were made. The Creative Commons Public Domain Dedication waiver (http://creativecommons.org/publicdomain/zero/1.0/) applies to the data made available in this article, unless otherwise stated. 
glaucoma, media opacity, previous pars plana vitrectomy, aphakia or other ocular condition where visual acuity would not improve with a resolution of edema. Only patients that completed 3 months of follow-up were included. All patients received the following intravitreal treatments: a combination of $1.25 \mathrm{mg}$ bevacizumab and $1 \mathrm{mg}$ triamcinolone acetonide.

In all patients best corrected visual acuity (BCVA), IOP measurement, slit lamp examination, fundus examination by indirect ophthalmoscopy and $90 \mathrm{D}$, fluorescein angiography and optical coherence tomography were done at baseline. The patients were followed up and comprehensively evaluated at 1 week, 1 month, 2 months and 3 months after injection. Visual acuity, central macular thickness, and IOP were recorded, and change was statistically analyzed using non-parametric tests like Wilcoxon signed ranks test and Mann-Whitney $U$ test. Fluorescein angiography was repeated at 3 months.

\section{Results}

A total of 21 patients that completed 3 months of follow-up, 10 patients with BRVO and 11 patients with CRVO. Mean age was 63.60 years $(S D=7.625)$. The baseline visual acuity in the CRVO and BRVO groups was 0.990 LogMAR $(S D=0.5301)$ and 0.630 LogMAR $(\mathrm{SD}=0.2669)$, respectively $(p=0.092)$. Central macular thickness (CMT) in the CRVO and BRVO patients was $572.50 \mu(\mathrm{SD}=118.838)$ and $381.70 \mu(\mathrm{SD}=80.705)$ respectively $(p=0.001)$. The baseline intraocular pressure (IOP) in the CRVO and BRVO was $15.30 \mathrm{~mm} \mathrm{Hg}$ $(\mathrm{SD}=3.199)$ and $13.50 \mathrm{~mm} \mathrm{Hg}(\mathrm{SD}=3.375)$, respectively $(p=0.237)$.

\section{Patients with Central Retinal Vein Occlusion}

Eleven patients were diagnosed with treated for CRVO. Mean initial visual acuity was logMAR $0.990(0.5301)$ and mean visual acuity at 1 month was logMAR $0.480(0.5432)$, at 2 months was logMAR $0.630(0.5417)$ and at final follow-up at 3 months was logMAR 0.840 (0.5777) $(p=0.02)$. Mean central macular thickness (CMT) was 572.502 (118.838) and at final follow-up at 3 months was 390.40 microns (120.301) ( $p=0.001)$.Elevation of IOP (>21 mm Hg) was seen in 4 patients. The rate of cataract development in the CRVO group was $10 \%$ (1 out of 10 ).

\section{Patients with Branch Retinal Vein Occlusion}

Ten patients were diagnosed with treated for BRVO. Mean initial visual acuity was logMAR $0.630(0.2669)$ and mean visual acuity at 1 month was logMAR 0.57 (0.231) at 2 months was logMAR 0.34 $(0.2591)$ at 3 months was logMAR $0.33(0.2908)(p=0.004)$, mean CMT was 381.70 (80.705) and at final follow up at 3 months was 250.30 microns (46.959) $(p=0.0002)$. Elevation of IOP (> $21 \mathrm{~mm} \mathrm{Hg})$ was seen in 5 patients. The rate of cataract development was $20 \%$ in the BRVO group (2 out of 10).

\section{Discussion}

RVOs typically occur as a result of arteriosclerosis and, hence, systemic cardiovascular risk factors $^{20,21}$ (e.g., hypertension, hyperlipidemia, and diabetes mellitus) play a key pathogenic role. In younger patients, hypercoagulability ${ }^{6}$ may also be a factor.

Firstly, serous exudation distal to the point of obstruction may result in macular edema; when the associated damage to the vascular architecture is severe, such edema may become prolonged or permanent with attendant degenerative changes (macular holes, epiretinal membranes, etc.). Secondly, retinal hemorrhages may be seen in the area drained by the retinal vein distal to its obstruction; in severe cases, dissection of blood beneath the retina may lead to retinal pigment epithelium (RPE) atrophy and/or scarring, often in a subfoveal location. Finally, the venous obstruction may be accompanied by ischemic damage to the retina, with extensive loss of the capillary bed and postischemic atrophic changes. When sufficient retinal ischemia is present, pathologic retinal neovascularization may ensue, resulting in vitreous hemorrhage and/or tractional retinal detachment, while iris neovascularisation may culminate in "neovascular" glaucoma, ${ }^{22,23}$ Rarely local ocular diseasesm, ${ }^{24}$ especially of an inflammatory nature may result in a secondary BRVO. This has been reported in diseases like toxoplasmosis, Eales' disease, Behçet's syndrome, and ocular sarcoidosis. Also, microaneurysms, Coats' disease, retinal capillary haemangioma, and optic disc drusens are linked to BRVO.

A variety of treatment options have been tried in the management of macular edema secondary to RVO. Lasers were the first successful management for BRVO. Subsequently, several treatment modalities were tried but were short-lived. Pharmacotherapy with intravitreal steroids and anti-VEGF agents have of late gained popularity in the reduction of macular edema. There appears to be a significant correlation between the reduction in central macular thickness and improvement in visual acuity. ${ }^{25}$

Tao et al. ${ }^{26}$ compared the effect of intravitreal bevacizumab versus intravitreal triamcinolone for the treatment of nonischaemic central retinal vein occlusion (CRVO) in a comparative nonrandomized retrospective clinical interventional study on 72 patients. They concluded that both are associated with a comparable gain in visual acuity while the reduction in macular edema was more marked in the triamcinolone group. However, in view of raised IOP in the triamcinolone group, the authors recommended bevacizumab intravitreal use in non-ischaemic CRVO.

Although combined therapy was earlier used for ARMD and diabetic retinopathy, however, its use in RVO was first reported by Ekdawi and Bakri ${ }^{27}$ who successfully treated a case with chronic macular edema secondary to CRVO which was refractory to intravitreal triamcinolone and intravitreal bevacizumab. Meanwhile, Schaal et al. ${ }^{28}$ proposed that one solution to avoid the decrease in the biologic effect of anti-VEGF therapy, which they attributed to tachyphylaxis, would be to combine drugs with different modes of action. They demonstrated that combining bevacizumab with triamcinolone acetonide partially alleviated the efficacy decrease observed with bevacizumab alone.

Ehrlich et al. ${ }^{18}$ evaluated the effects of combined treatment of intravitreal bevacizumab and intravitreal triamcinolone in patients with retinal vein occlusion over 6 months. In their retrospective consecutive case series, they injected Intravitreal bevacizumab $(1.25 \mathrm{mg})$ combined with intravitreal triamcinolone $(2 \mathrm{mg})$ in 16 patients with RVO (8 CRVO and 8 BRVO). They concluded that combined treatment with intravitreal bevacizumab and intravitreal triamcinolone improves structural outcome in patients with retinal vein occlusion but offers no advantage over previously published results with intravitreal bevacizumab injections alone for improving vision at 6 months.

Çekiç et al. ${ }^{19}$ compared the efficacy of intravitreal injection of triamcinolone, bevacizumab, and a combination of triamcinolonebevacizumab for the management of macular edema due to branch retinal vein occlusion. In their study of 52 patients $(29$ male, 23 female), the three treatment arms included; intravitreal $4 \mathrm{mg}$ triamcinolone acetonide, intravitreal $1.25 \mathrm{mg}$ bevacizumab and an intravitreal combination of $2 \mathrm{mg}$ triamcinolone acetonide and 1.25 mg bevacizumab. All study groups showed significant reduction of central macular thickness at one month, however, at 6 months, 
Table 1: Studies on combined use of intravitreal bevacizumab and intravitreal triamcinolone in patients with retinal vein occlusion

\begin{tabular}{|c|c|c|c|c|c|}
\hline & Number of eyes & Type of involvement & Study design & Intervention & Result \\
\hline Ehrlich et al. ${ }^{18}$ & 16 & 8 BRVO; 8 CRVO & $\begin{array}{l}\text { Retrospective case } \\
\text { series }\end{array}$ & IVT and IVB & $\begin{array}{l}\text { Improved CMT at } 6 \text { months } \\
\text { but only BRVO had improved } \\
\text { VA at } 6 \text { months. }\end{array}$ \\
\hline Çekiç et al. ${ }^{19}$ & 52 & BRVO & $\begin{array}{l}\text { Prospective, } \\
\text { randomized }\end{array}$ & $\begin{array}{l}\text { IVT }(n=17), \text { IVB }(n=14) \\
\text { or IVT and IVB }(n=21)\end{array}$ & $\begin{array}{l}\text { Improved CMT and VA at } 1 \\
\text { month in all groups without } \\
\text { difference amongst them. } \\
\text { Only IVB group had improved } \\
\text { VA at } 6 \text { months }\end{array}$ \\
\hline Ali et al. ${ }^{29}$ & 20 & BRVO & $\begin{array}{l}\text { Retrospective case } \\
\text { series }\end{array}$ & IVT \& IVB & $\begin{array}{l}\text { Improved CMT and VA at } 6 \\
\text { months }\end{array}$ \\
\hline Lee et al. ${ }^{30}$ & 151 & BRVO & $\begin{array}{l}\text { Retrospective case } \\
\text { series }\end{array}$ & $\begin{array}{l}\text { IVT }(n=31), \text { IVB }(n=95) \\
\text { IVT and IVB }(n=25)\end{array}$ & $\begin{array}{l}\text { Improved CMT and VA in } \\
\text { combination group }\end{array}$ \\
\hline Moon et al. ${ }^{31}$ & 41 & BRVO & $\begin{array}{l}\text { Prospective, } \\
\text { randomized }\end{array}$ & $\begin{array}{l}\text { IVB }(n=23), \text { or IVB and } \\
\text { STA }(n=18)\end{array}$ & $\begin{array}{l}\text { CMT and VA same between } \\
\text { groups at } 6 \text { months, however } \\
\text { reduced number of additional } \\
\text { IVB injections required in } \\
\text { combination group }(p=0.034)\end{array}$ \\
\hline $\begin{array}{l}\text { Motarjemizadeh } \\
\text { et al. }^{32}\end{array}$ & 90 & CRVO & $\begin{array}{l}\text { Double-blinded } \\
\text { randomized clinical } \\
\text { trial }\end{array}$ & $\begin{array}{l}\text { IVT }(n=30), \operatorname{IVB}(n=30) \\
\text { IVT and IVB }(n=30)\end{array}$ & $\begin{array}{l}\text { IVB or IVT + IVB with or } \\
\text { without rescue laser treatment } \\
\text { resulted in improvement in } \\
\text { visual acuity at } 24 \text { months }\end{array}$ \\
\hline Present & 21 & 10 BRVO; 10 CRVO & $\begin{array}{l}\text { Prospective case } \\
\text { series }\end{array}$ & IVT and IVB & $\begin{array}{l}\text { Improved CMT and VA at } \\
3 \text { months in both CRVO and } \\
\text { BRVO }\end{array}$ \\
\hline
\end{tabular}

while there was a significant reduction in central macular thickness, only bevacizumab group demonstrated significant improvement in visual acuity. They concluded that all three groups appeared to have similar therapeutic effects on macular edema, however intravitreal injection of bevacizumab yielded better results of visual acuity than the others at six months.

Since these initial reports, few other authors have conducted similarstudies on combined therapy for retinal vein occlusions(Table 1). However, 4 out of 6 reports have included only BRVO while one report each included only CRVO and combined BRVO and CRVO. We observed results similar to these reports with significant improvement in visual acuity in the CRVO group at all visits and the BRVO group showed significant visual improvement at 4 weeks, 8 weeks and 12 weeks of follow-up after injection. Although most authors reported some beneficial effect of combined therapy, however, the final conclusion varies between reports owing to different study design, inclusion criteria, and intervention protocol.

In conclusion, combined treatment with intravitreal bevacizumab and intravitreal triamcinolone acetonide cause structural and functional improvement in the form of reduction of macular edema and improvement in visual acuity in eyes with both Branch retinal vein occlusion and Central retinal vein occlusion. However, there is a need to conduct a larger multicentric randomized controlled trial to ascertain the best treatment protocol for RVOs.

\section{References}

1. Hayreh SS. Prevalent misconceptions about acute retinal vascular occlusive disorders. ProgRetin Eye Res 2005;24:493-519.

2. Bearelly S, Fekrat S. Controversy in the management of retinal venous occlusive disease. Int Ophthalmol Clin 2004;44(4):85-102.

3. Mohamed $\mathrm{Q}, \mathrm{McIntosh} \mathrm{RL}$, Saw SM, et al. Interventions for central retinal vein occlusion: an evidence-based systematic review. Ophthalmology 2007;114:507-519,524.
4. McIntosh RL, Mohamed Q, Saw SM, et al. Interventions for branch retinal vein occlusion: an evidence-based systematic review. Ophthalmology 2007;114:835-854.

5. The Branch Vein Occlusion Study Group. Argon laser photocoagulation for macular edema in branch vein occlusion. Am J Ophthalmol 1984; 98:271-282.

6. The Central Vein Occlusion Study Group. Evaluation of grid pattern photocoagulation for macular edema in central vein occlusion. The central vein occlusion study group M report. Ophthalmology 1995; 102:1425-1433.

7. Krepler K, Ergun E, Sacu S, et al. Intravitreal triamcinolone acetonide in patients with macular oedema due to branch retinal vein occlusion: a pilot study. Acta Ophthalmol Scand 2005;83(5): 600-604.

8. Jonas JB, Kreissig I, Degenring RF. Intravitreal triamcinolone acetonide as treatment of macular edema in central retinal vein occlusion. Graefes Arch Clin Exp Ophthalmol 2002;240(9):782-783.

9. Çekiç O, Chang S, Tseng JJ, et al. Intravitreal triamcinolone injection for treatment of macular edema secondary to branch retinal vein occlusion. Retina 2005; 25:851-855.

10. Çakır M, Doğan M, Bayraktar Z, et al. Efficacy of intravitreal triamcinolone for the treatment of macular edema secondary to branch retinal vein occlusion in eyes with or without grid laser photocoagulation. Retina 2008;28:465-442.

11. Campochiari PA, Heier JS, Feiner $L$, et al. Ranibizumab for macular edema following branch retinal vein occlusion: twelve-month outcomes of a phase III study. Ophthalmol 2011;118:1102-1111.

12. Campochiaro PA, Brown DM, Awh CC, et al. Sustained Benefits from Ranibizumab for Macular Edema following Central Retinal Vein Occlusion: Twelve-Month Outcomes of a Phase III Study. Ophthalmology 2011 Oct;118(10):2041-2049.

13. Stahl A, Agostini $H$, Hansen $L L$, et al. Bevacizumab in retinal vein occlusion-results of a prospective case series. Graefe's Clin Exp Ophthalmo 2007;245:1429-1436.

14. Jaissle GB, Leiritz M, Gelişken F, et al. One-year results after intravitreal bevacizumab therapy for macular edema secondary to branch retinal vein occlusion. Graefe's Clin Exp Ophthalmol 2009;247:27-33. 
15. Vinten $M$, Larsen $M$, Lund-Anderson $H$, et al. Short-term effects of intravitreal triamcinolone on retinal vascular leakage and trunk vessel diameters in diabetic macular edema. Acta Ophthalmol Scand; 85: 21-26.

16. Zhang X, Bao S, Lai D, et al. Intravitreal triamcinolone acetonide inhibits breakdown of the blood-retinal barrier through differential regulation of VEGF-A and its receptors in early diabetic rat retinas. Diabetes 2008;57(4):1026-1033.

17. Ferrara N, Damico L, Shams N, et al. Development of ranibizumab, an anti-vascular endothelial growth factor antigen binding fragment, as therapy for neovascular age-related macular degeneration. Retin. 2006;26(8):859-870.

18. Ehrlich R, Ciulla TA, Moss AM, et al. Combined treatment of intravitreal bevacizumab and intravitreal triamcinolone in patients with retinal vein occlusion: 6 months of follow-up. Graefes Arch Clin Exp Ophthalmol. DOI 10.1007/s00417-009-1211-6.

19. Çekiç O, Çakır M, Yazıcı AT, et al. A Comparison of Three Different Intravitreal Treatment Modalities of Macular Edema Due to Branch Retinal Vein Occlusion Current Eye Research 2010;35(10): 925-929.

20. Rath EZ, Frank RN, Shin DH, et al. Risk factors for retinal vein occlusions. A case-control study. Ophthalmology 1992;99:509-514.

21. Elman MJ, Bhatt AK, Quinlan PM, et al. The risk for systemic vascular diseases and mortality in patients with central retinal vein occlusion. Ophthalmology 1990;97:1543-1548.

22. Mclntosh RL, Rogers SL, Lim L, et al. Natural history of central retinal vein occlusion: an evidence-based systematic review. Ophthalmology. 2010;117:1113-1123.e1115.

23. Rogers SL, McIntosh RL, Lim L, et al. Natural history of branch retinal vein occlusion: an evidence-based systematic review. Ophthalmology. 2010; 117:1094-1101.e1095.
24. Morley MG, Heier JS. Yanoff \& Duker: Ophthalmology, 3rd ed. 2008 Mosby, an imprint of Elsevier. p. 2134-2137.

25. Scott I, Van Veldhuisen P et al.SCORE Study Report 1: Baseline Associations between Central Retinal Thickness and Visual Acuity in Patients with Retinal Vein Occlusion. Ophthalmology 2009 March;116(3):504-512.

26. Tao $Y$, Hou J, Jiang $Y R$, et al. Intravitreal bevacizumab versus triamcinolone acetonide for macular edeme due to central retinal vein occlusion. Eye (Lond) 2010 May;24(5):810-815.

27. Ekdawi NS, Bakri SJ. Intravitreal triamcinolone and bevacizumab combined therapy for macular edema due to central retinal vein occlusion refractory to either treatment alone. Eye 2007;21(8):1128-1130.

28. Schaal S, Kaplan HJ, Tezel TH. Is there tachyphylaxis to intravitreal anti-vascular endothelial growth factor pharmacotherapy in agerelated macular degeneration? Ophthalmology 2008;115:2199-205.

29. Ali RI, Kapoor KG, Khan AN, et al. Efficacy of combined intravitreal bevacizumab and triamcinolone for branch retinal vein occlusion. Indian J Ophthalmol 2014 Apr;62(4):396-399. doi: 10.4103/03014738.120227.

30. Lee K, Jung H, Sohn J. Comparison of Injection of Intravitreal Drugs with Standard Care in Macular Edema Secondary to Branch Retinal Vein Occlusion. Korean Journal of Ophthalmology: KJO 2014;28(1):19-25.

31. Moon J, Kim M, Sagong M. Combination therapy of intravitreal bevacizumab with single simultaneous posterior subtenon triamcinolone acetonide for macular edema due to branch retinal vein occlusion. Eye (Lond) 2016 Aug;30(8):1084-1090.

32. Motarjemizadeh G, Rajabzadeh M, Aidenloo NS, et al. Comparison of treatment response to intravitreal injection of triamcinolone, bevacizumab and combined form in patients with central retina vein occlusion: A randomized clinical trial. Electron Physician 2017 Aug 1;9(8):5068-5074. 